\title{
Pengaruh partikel filler terhadap modulus elastisitas resin komposit Effect of filler particles on the elastic moduli of resin composites
}

\author{
Veni Takarini, Nina Djustiana, Renny Febrida \\ Bagian Ilmu dan Teknologi Material Kedokteran Gigi \\ Fakultas Kedokteran Gigi Universitas Padjadjaran \\ Bandung, Indonesia
}

\begin{abstract}
Modulus of elasticity is one of the mechanical properties of composite resins affects the resistance to deformation, the strength of bonding with tooth structure and wear resistance. Modulus of elasticity is determined by the volume fraction of filler particles as the inorganic phase composite resin. This literature study aims to evaluate the size, shape and type of filler particles that affect the modulus of elasticity for composite resin. In a constant volume fraction, the larger size of filler material tends to make more rigid while irregular shape of particles produces higher modulus of elasticity than spherical form of particles. In addition, the type of filler particles also determines the modulus of elasticity for resin composite, such as silica as the main type of filler particles will enhance the modulus of elasticity whereas zirconium can result in a higher stiffness. In order to get composite resin restoration with appropriate modulus of elasticity the necessary knowledge about the effect of different filler particle is required.
\end{abstract}

Keywords: filler volume fraction, particle filler, modulus of elasticity, resin composite

\begin{abstract}
ABSTRAK
Modulus elastisitas merupakan salah satu sifat mekanis resin komposit yang mempengaruhi ketahanan terhadap deformasi, kekuatan ikat dengan struktur gigi, serta wear resistance. Modulus elastisitas ditentukan antara lain oleh volume fraction partikel filler sebagai fasa inorganik resin komposit. Studi kepustakaan ini bertujuan untuk mengevaluasi ukuran, bentuk, dan jenis partikel filler yang mempengaruhi modulus elastisitas resin komposit. Dalam suatu volume fraction yang konstan, ukuran filler yang lebih besar cenderung membuat bahan lebih kaku dan bentuk partikel tidak seragam menghasilkan nilai modulus elastisitas yang lebih tinggi dibanding bentuk partikel spherical. Selain itu, jenis partikel filler juga menentukan modulus elastisitas resin komposit, seperti silika yang merupakan jenis utama partikel filler dapat meningkatkan modulus elastisitas, sedangkan partikel filler jenis lain seperti zirkonium dapat menghasilkan kekakuan yang lebih tinggi. Untuk mendapatkan restorasi resin komposit dengan modulus elastisitas yang memadai, maka diperlukan pengetahuan mengenai pengaruh kandungan partikel filler yang berbeda.
\end{abstract}

Kata kunci: filler volume fraction, partikel filler, modulus elastisitas, resin komposit

Koresponden: Veni Takarini, Bagian Ilmu Teknologi Material Kedokteran Gigi, Fakultas Kedokteran Gigi Universitas Padjajaran, Jl. Sekeloa Selatan No.1, Bandung, Indonesia. E-mail:vtakarini.drg@unpad.ac.id 